\begin{tabular}{|c|c|c|}
\hline & $\begin{array}{l}\text { RONMENTAL AND CLIMATE } \\
\text { TECHNOLOGIES }\end{array}$ & \multirow{2}{*}{ 2009-5208 } \\
\hline $\begin{array}{l}\text { ISSN 1691-5208 } \\
10.2478 / v 10145-009-0018-3\end{array}$ & $\begin{array}{c}\text { VIDES UN KLIMATA } \\
\text { TEHNOLOGIJAS }\end{array}$ & \\
\hline
\end{tabular}

\title{
THE ANALYSIS OF NOISE LEVEL ON SAULKARSTI BYPASS, LATVIA
}

\section{TROKŠṆU LĪMEN̦A ANALĪZE UZ SAULKRASTU APVEDCEḶA}

\author{
A.Zandberga, MSc .ing., \\ Institute of Energy Systems and Environment, Riga Technical university. \\ Address: Kronvalda boulv. 1, LV-1010, Riga, Latvia \\ Phone: +371 67089908, Fax:+37167089908 \\ e-mail: anda.zandberga@,rtu.lv \\ L. Lieplapa, MSc geol., Researcher, $\mathrm{PhD}$ student, \\ Institute of Energy Systems and Environment, Riga Technical university. \\ Address: Kronvalda boulv. 1, LV-1010, Riga, Latvia \\ Phone: +371 67089908, Fax:+37167089908 \\ e-mail: liga.lieplapa@rtu.lv \\ D. Blumberga, Dr.habil.sc.ing., Prof., Head of \\ Institute of Energy Systems and Environment, Riga Technical university. \\ Address: Kronvalda boulv. 1, LV-1010, Riga, Latvia \\ Phone: +371 67089908, Fax:+37167089908 \\ e-mail:dagnija@btv.lv
}


Keywords: correlation coefficient, environmental impact assessment, level marking method, noise, traffic intensity

\section{Introduction}

Along the development of the country, buildings and factories are constructed and the infrastructure is being upgraded. One of the infrastructure objects that requires environmental impact assessment (EIA) for construction are roads. Any project has an impact upon environment, both positive and negative, therefore it is important to analyze different EIA indicators in construction and operation of linear infrastructures (roads incl.).

In order to carry out complete environmental impact assessment, it is important to determine environmental indicators in road construction and specify what kind of environmental parameters should be measured or modeled during the design, construction and operation stages. In case of road construction it is necessary to examine environmental indicators that are used for pollution emission levels in the air, soil and water, impact on animals, the levels of noise.

The aim of this work is to determine the real noise level after road construction, appraise the accuracy of EIA prognosis and find out the correlation between noise level and traffic intensity. In this paper is explained the noise level measurement method, obtained data analysis and correlation results for new bypass.

Saulkrasti bypass has been selected as the object for the research. Saulkrasti bypass is the first newly constructed motorway section in Latvia since the regaining of its independence. The total length of the motorway constructed within the framework of VIA BALTICA, is $20.24 \mathrm{~km}$. The goal for the construction of bypass was to relieve the city of Saulkrasti from traffic, basically from transit traffic, i.e., by $50 \%$ of automobiles and by $100 \%$ of freight transport. The construction works were started in 2005 and the road put into operation in 2007. For the first time in the history of Latvia, the sound proof walls have been installed along the motorway covering the area of 4000 $\mathrm{m}^{2}$ at the locations where the excess of noise levels from motorway has been forecast within EIA.

\section{The description of noise indicator}

The noise indicator was studied in context of the populated area, its social functioning and sensitivity towards the noise emissions.

The biggest prognosed value of noise emission was assumed to determine the boundaries of criteria. It is based on the assumption that sound propagation is usually the most far-reaching impact of the road traffic [1]. This approach also seems right because this factor is directly concerned with the health and well-being of residents, that is one of the most essential issues of EIA. The impact of noise on the wild species and their migration activities is not discussed here due to the lack of data.

The noise level should be examined starting with the initial planning and design stage of the project. This ensures that the control measurements of noise impact are integrated in all stages of the road design. The existing environmental noise is measured, followed by noise forecast that the new road project is expected to generate after completion and added to the background noise. The following is considered when the noise of the road traffic is being examined: the percentage of trucks and automobiles during daytime and nighttime, the speed of traffic, the road surface, topography, height and distance the of noise recipient, the topographic barriers of the road [2].

After the construction period the actual level of noise has to be measured. It helps to assess the precision of the noise level estimates, the efficiency of measures for decreasing the noise and the necessity of such measures $[2,1]$.

In order to assess the efficiency of noise protection walls, the measurements have to be carried out before and after their installation. To preserve the integrity of measurement data it is always necessary to carry out the measurements in the same locations. The noise boundary values have to be indicated in the EIA report so that the community would be able to draw meaningful conclusions on the significance of the noise impacts. 
An additional area 300 meters wide has been designated for more detailed study of flora and fauna the central section of pollution emission upon habitats [1]. The method that has been chosen for evaluation of separate environmental factors provides a qualitative description or is partly quantitative rather than mathematically quantitative.

According to EIA it is envisaged that the planned bypass will divert all of the international transport from the roads of populated areas. This will give significant relief since the international transportation is usually heavy cargo trucks $(7.5-32 \mathrm{t})$, that cause the strongest vibration as well as the most noise and air pollution [1, 2].

\section{Methodology of measurements}

The procedure of noise estimation is stipulated by the Regulations No.597 [3] of the Cabinet of Ministers of the Republic of Latvia where it is stated that for estimating noise indicators, the length of day is considered to be 12 hours, the evening is 4 hours and the night -8 hours. The daytime is from 7.00 till 19.00 , the evening from $19.00-23.00$, and the night from 23.00 - 7.00. When night $\left(\mathrm{L}_{\mathrm{n}}\right)$ and day $\left(\mathrm{L}_{\mathrm{d}}\right)$ noise indicators are evaluated the direct sound and not the sound reflecting from the front of the particular building is to be taken into account. To compensate for the reflected sound the measurement is to be corrected by minus $3 \mathrm{~dB}(\mathrm{~A})[3]$. The measurements are not to be carried out lower than 1.5 meters from the soil surface, but the results are adjusted for the height of 4 meters. The duration of measurements is no less than 3 minutes. When selecting the location of measurement, crossroads and the vicinity of forests have to be avoided. The measurements are not allowed when the asphalt is wet. The measurements have to be carried out at low wind velocity (preferably below 3,3-5,4 m/s) and they should be done in various kinds of places, to allow for a more representative sample. The environmental noise measurements are carried out with calibrated tools. We made our measurements by the help of SVAN 945A sound level meter and analyzer, measuring Leq indicator (Equivalent Sound Level) that quantifies the noise environment as a single value of sound level for any desired duration [4].

The tool is used for general acoustic measurements and environmental noise monitoring. Three acoustic profiles allow for simultaneous measurements. The temperature and statistic pressure sensors are built-in this device. The device allows for measurements of tonality and loudness. Resolution is $0.1 \mathrm{~dB}$. It is operable in temperatures from $-10^{\circ} \mathrm{C}$ till $50^{\circ} \mathrm{C}$.

The measurement error of SVAN $945 \mathrm{~A}$ is $\pm 0.7 \mathrm{~dB}$. Uncertainty is said to be within the range of $\pm 3 \mathrm{~dB}$.
The physics of noise is a complicated matter and when measuring noise, both sound reflection and absorption have to be taken into account. The appropriate place has to be selected so that the sound would not reflect from the front of the house or other obstacle. If this is not possible, it has to be compensated for, during the analysis of results. The wind direction and velocity also affect the amount of noise measured. If the distance from the source of noise increases, the level of certainty for evaluation of the level of noise sharply decreases. In our case, the distance from the motorway was not the same in all cases.

The uncertainty is important for noise measurement also in this study, because the road as a system is complex. The noise level measurements depend from many factors and one of them is human. When the system becomes too complicated, in order to deal with all of the parameters, simplification of one or more parameters is necessary. In other words, the separation of model or system is necessary. If the system is modeled as the real, it is possible to measure the usefulness of the model in empirical way. The reliance on the model depends on the degree to which it is expected to model the reality.

W.D.Rowe [5] enumerates the sources of uncertainty that had appeared due to the system's complexity:

- $\quad$ Characteristic random processes;

- $\quad$ Degree of complexity;

- The parameter dependence on one from another;

- The initial condition of chaotic systems;

- Incomplete information about all of the

parameters.

Inaccurate measurements are one of the sources of uncertainty. Precision refers to the correctness by which the readings of the tool scales have been established. Inaccurate measurements are another source of uncertainty, but it is one that could be theoretically corrected. It is very important to understand the error of measurement and its size, relative with respect to changing features which are measured [6].

In our experiment the noise level from bypass has been measured on working days ( 5 days from March $4^{\text {th }}$ till April $1^{\text {st }}$ with interval of 1 week) 10 minutes in every hour (in day time from 9.00 am till $6.00 \mathrm{pm}$ ). 4 measurement places (Saulaina ieleja, Kursi, Parupes iela and Medzabaki) have been chosen along the bypass, where residential or municipal buildings are close to the road.

The measurement of traffic intensity (TI). In international practice the traffic intensity is commonly measured with electronic devices or special cameras, but if it is done manually, 3 groups of measurement periods are recommended; working days, weekends and holidays. In order to measure the normal and high traffic intensity, usually the weekends are not counted 
for, since the traffic intensity is lower in those days. This is not the same for public holidays, since the traffic in these days are normal or high. The normal and high traffic intensity is defined by taking into consideration the period of month. The working days can be chosen only when it is clear that the traffic during weekends will be less than on working days. In our experiment we examined the traffic intensity in 4 above mentioned places on working days ( 5 days from March $4^{\text {th }}$ till April $1^{\text {st }}$ with interval 1 of week) and were counting vehicles every 20 minutes (from $9.00 \mathrm{am}$ till $6.00 \mathrm{pm})$. We were separately counting trucks, automobiles, public transportation and motorcycles.

\section{The results. The mutual connection between noise and traffic intensity}

The level marking method is used in the analysis of results that include the determination of boundary values and the comparison of the obtained results, all of that is represented in a Fig.1.

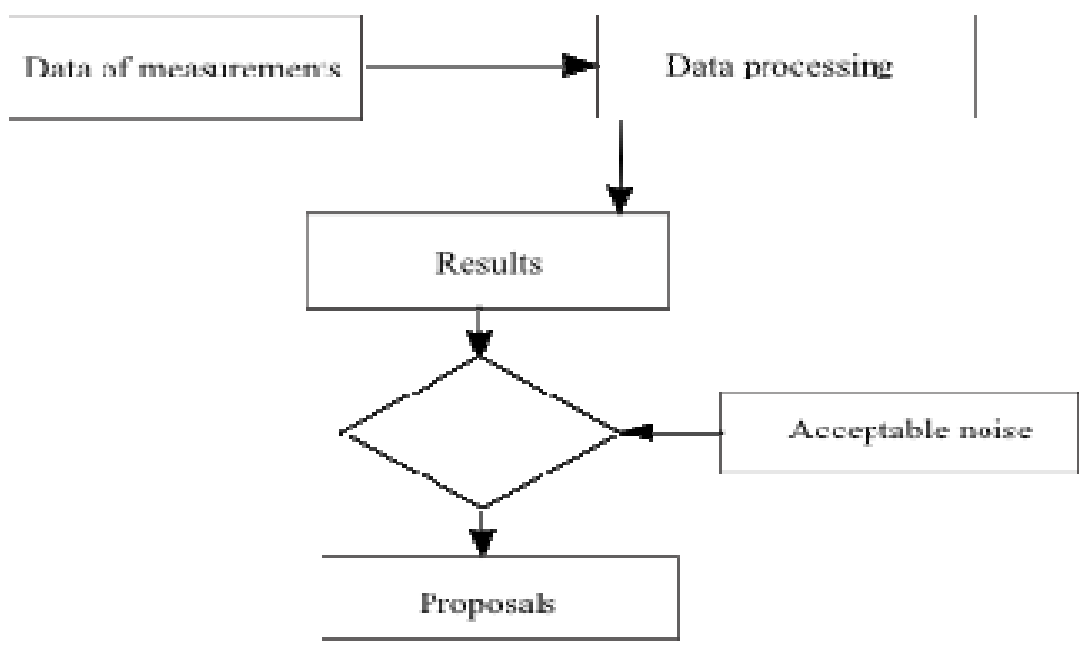

Fig.1. The algorithm of level marking method

The level marking method includes the modules for data measurement and processing, from which it is possible to obtain the results that are comparable with the allowable levels of noise. The data have to be credible and they have to determine the uncertainty of calculation of measurements.

The determination of the noise level took place during one part of the day (daytime) and it was determined only in two seasons: the spring and winter. The results of measurements of noise levels are represented in a Fig.2.

The level marking method is graphically presented by drawing the boundary values (see the uninterrupted line in Fig.2), that characterizes the allowable level of noise during the daytime.

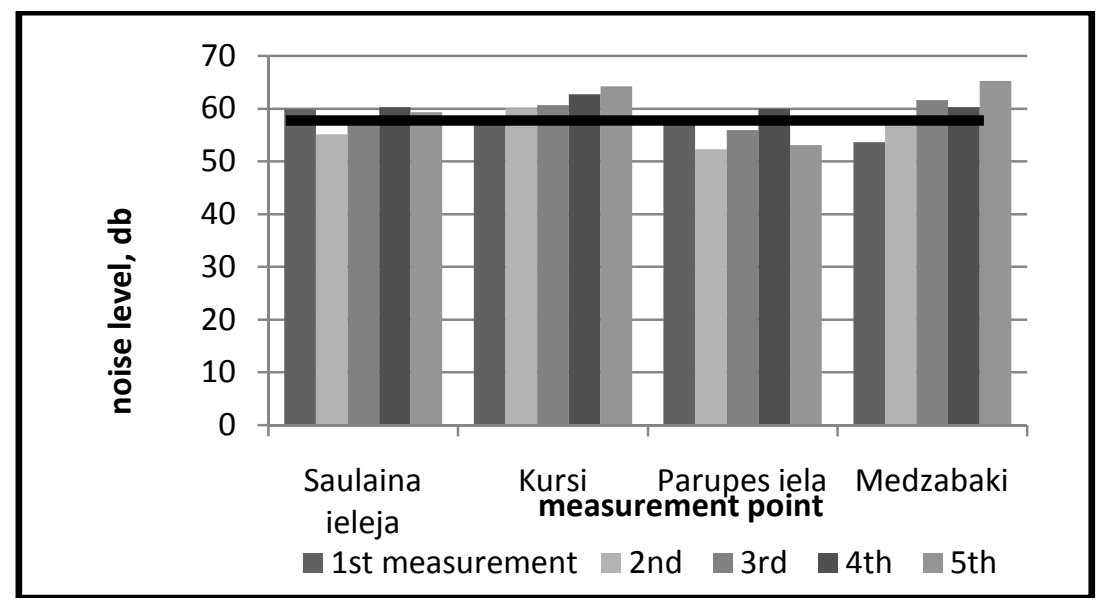

Fig.2. The indicators of noise level

As it is seen from Fig.2, the acceptable noise level (55 $\mathrm{db}$ in day time) is exceeded in all of the cases. It means that during the season when the traffic intensity is low, the indicators of noise measurement are high. There is 
also excess of noise in the places (Medzabaki and Saulaina Ieleja), where the noise proof wall has been installed (the acceptable noise level is $55 \mathrm{db}$ in daytime).

The traffic intensity on the bypass is 220 vehicles per 1 hour, $1 / 3$ of them are heavy transport, lorries. The traffic intensity have influence on the air quality and noise level, proved also by lines of correlation in Fig.3. The credibility assessment of determination of data acquisition and conduct of measurements is accomplished by data regression analysis. The correlation coefficient is the quantitative indicator of connection tightness between two or more variables. The correlation coefficient is marked with the letter " $r$ " and its value is ranging from -1 till +1 , if:

1. $\mathrm{r}=-1$, it is negative linear connection.

2. $r=0-$ doesn't exist correlation.

3. $\mathrm{r}=1-$ positive.

4. $|\mathrm{r}|<0.5-$ weak.

5. $\quad 0.5<|\mathrm{r}|<0.8$ - fairly tight.

6. $|\mathrm{r}|>0.8$ - tight $[7,8,9]$.

The correlation of traffic intensity and noise is represented

Fig.3.

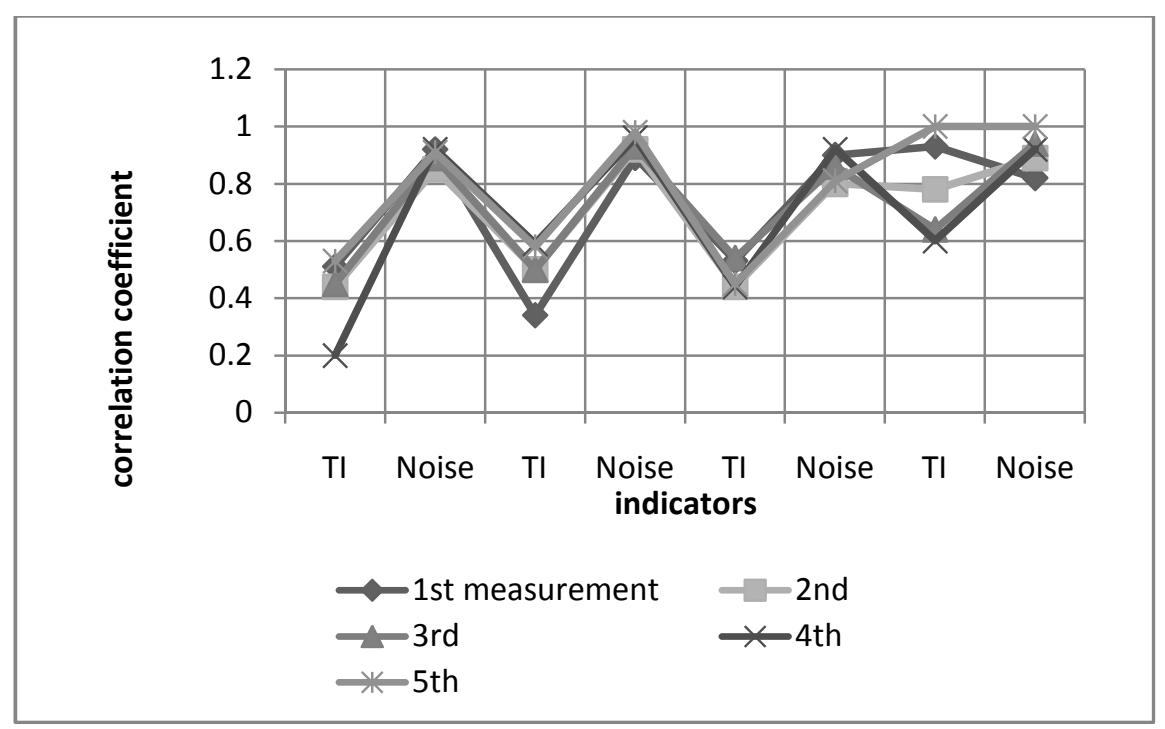

Fig.3. Correlation between traffic intensity (TI) and noise level

The correlation coefficients has been calculated for the highest noise level in $\mathrm{dB}$ and highest traffic intensity. Very tight correlation were registered between values above 0.8 (only 3 measurements in Medzabaki). The correlation in other measurements are week or bad. Values of correlation coefficients are presented in Table 1.

The correlation coefficients

Table 1.

\begin{tabular}{|l|r|r|r|r|r|r|r|r|}
\hline Measurement' point & \multicolumn{2}{l|}{ Saulaina ieleja } & \multicolumn{2}{l|}{ Kursi } & \multicolumn{2}{l|}{ Parupes iela } & \multicolumn{2}{l|}{ Medzabaki } \\
\hline Indicators & \multicolumn{1}{l|}{ TI* } & \multicolumn{1}{l|}{ Noise } & \multicolumn{1}{l|}{ II } & \multicolumn{1}{l|}{ Noise } & \multicolumn{1}{l|}{ TI } & \multicolumn{1}{l|}{ Noise } & \multicolumn{1}{l|}{ TI } & Noise \\
\hline $1^{\text {st }}$ measurement & 0.51 & 0.92 & 0.34 & 0.89 & 0.53 & 0.9 & 0.93 & 0.82 \\
\hline $2^{\text {nd }}$ measurement & 0.44 & 0.85 & 0.5 & 0.92 & 0.44 & 0.8 & 0.78 & 0.89 \\
\hline $3^{\text {rd }}$ measurement & 0.45 & 0.89 & 0.5 & 0.93 & 0.54 & 0.86 & 0.64 & 0.94 \\
\hline $4^{\text {th }}$ measurement & 0.2 & 0.92 & 0.59 & 0.96 & 0.44 & 0.92 & 0.6 & 0.92 \\
\hline $5^{\text {th }}$ measurement & 0.53 & 0.91 & 0.58 & 0.98 & 0.45 & 0.81 & 1 & 1 \\
\hline
\end{tabular}

* TI - traffic intensity

The average value of correlation coefficients is a bit over $0.3(|\mathrm{r}|$ is 0.35$)$.

That values are estimated as a weak or bad correlation. That could be based on such circumstances: the noise level' measurements have been done by several operators (human factor), the distance from bypass till each of measurement points were different. The noise level is depending also from wind direction, and speed, earth surface relief and objects in the concrete place. The results also are impacted by driving style, traffic intensity, seasonality and small number of measurements. 
In Fig.4 is showed the average day dates on noise level and traffic intensity obtained during measurements in 4 places. The assumption that to increase of traffic intensity the noise level is higher in generally is correct except the place Medzabaki.

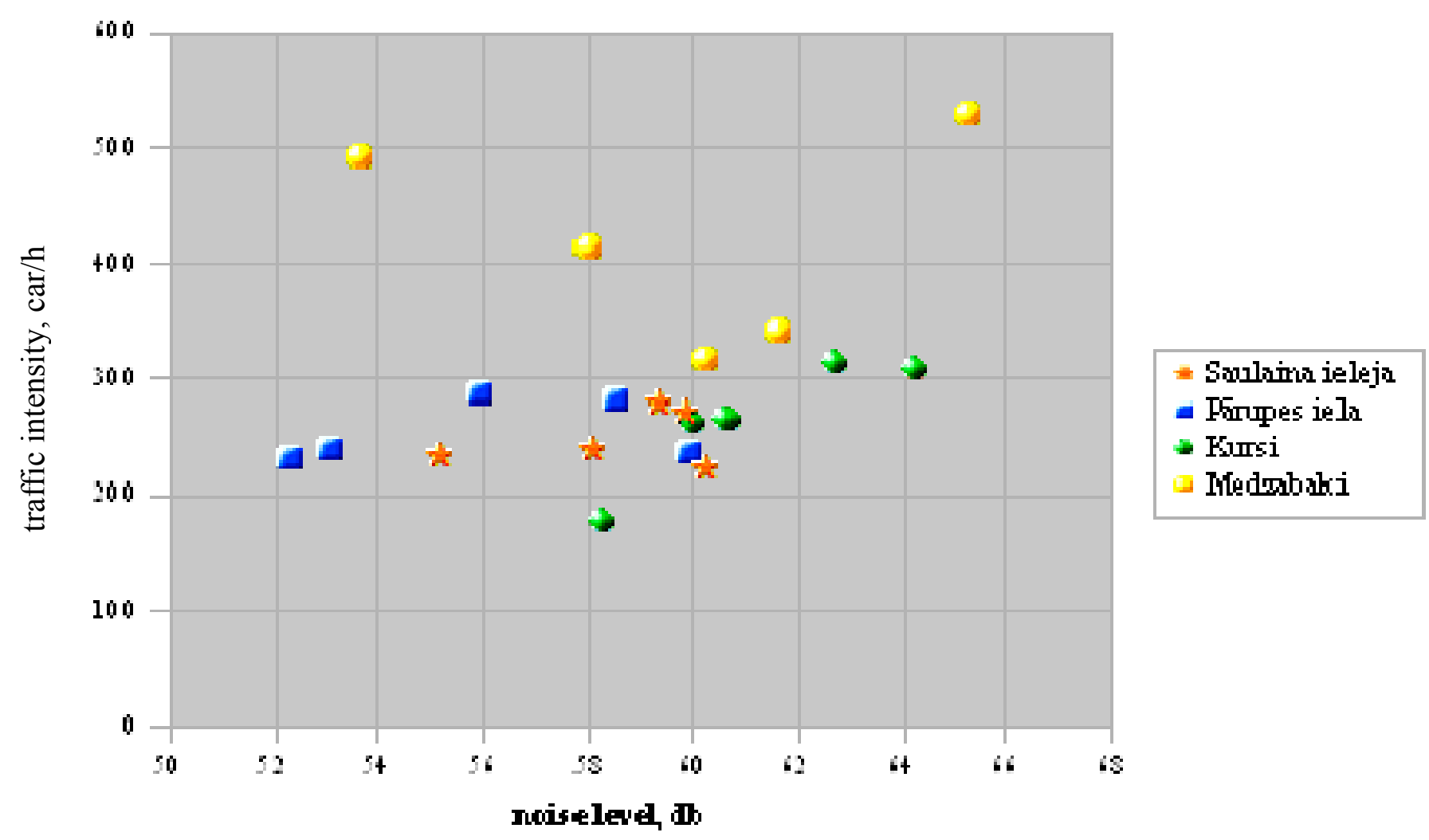

Fig.4. Relation between traffic intensity and noise level

\section{Conclusions}

The noise level from Saulkrasti bypass in result of EIA was predicted in acceptable interval (till $55 \mathrm{db}$ in daytime). The experimental measurements are showed that during the winter and spring seasons, when the traffic intensity is low, the noise level from the Saulkrasti bypass is exceeded in all of the measured points (4 places). There is also excess of noise in the places, where the noise proof wall has been installed (Medzabaki and Saulaina Ieleja). It's means that installed proof walls aren't enough effective.

The noise monitoring should be carried out on already functioning roads, to determine real situation and, if necessary, chose effective measures for decreasing of noise impact on inhabitant. The obtained monitoring data should be compared with prognoses during EIA (with modeling results) to appraise the accuracy of method of prognosis. Our experiment shows that prognosed noise level are lover than in real.

This experiment shows that the correlation between noise level and traffic intensity is weak., The reasons of them could be low number of measurements, failure of measurements in night time and human factor also.

\section{References}

1. Transport Air and Noise Pollution/http://www.transport.bham.ac.uk/research/ Airandnoise.shtml. - 08.03.2009.

2. Roads and the Environment http://web.worldbank.org. (11.02.2009)

3. The regulations Nr. 597 of the Council of Ministers of Latvia "The evaluation of environmental noise"// "Latvijas Vēstnesis" . - Issue No. 112 (3060), (23.07.2004).

4. The Engineering ToolBox www.engineeringtoolbox.com - 10.06.2009.

5. Rowe, W.D., 1994. Understanding uncertainty. Risk Analysis, 14, 743-750.

6. EA co-ordination with landscape planning in Germany / Prof. Dr. Catrin Schmidt, 2007 www.htpp://tu-dresden.de - 12.03.2009

7. Glasson J., Therivell R., Chadwick A. Introduction to environmental impact assessment - London and New York ,Routhledge. 3rd edition, 2005 - P.417. 
8. Grima A.P., Timmerman P.P., Fowle C.D., Byer P. Risk management and EIA. Research needs and opportunities // www.ceae.gc.ca/content 17.05.2009.

9. Hellstom T., Jacob M. Uncertainty and values. The case of Environmental Impact Assessment.

Anda Zandberga, Līga Lieplapa, Dagnija Blumberga, Trokšņu līmen̦a analīze uz Saulkrastu apvedcẹ̦a

Ietekmes uz vidi novērtējums (IVN) ir pasaulē atzīta metode paredzētās darbības, tai skaitā, lineāro infrastruktūru, radīto iespējamo izmainu vidē prognozei. Latvijā plānoto autoceļu būvniecības vai rekonstrukcijas projektu IVN parasti tiek veikts salīdzinoši ìsā laika posmāa, tādējādi nenodrošinot datus pietiekamā kvalitātē par esošo vides stāvokli, kas ietekmē prognožu rezultātus par vides kvalitātes iespējamām izmaiñām pēc paredzètāas darbības ieviešanas. Tas attiecas arī uz trokšñna lìmeņa izmaiņu prognozi pēc projekta realizācijas, ko pierāda veiktais pētījums uz Saulkrastu apvedceļa. IVN ietvaros, izmantojot modelēšanas metodi, tika prognozēts, ka autotransporta radītais troksnis nepārsniegs normatīvos robežlielumus, bet problemātiskajās vietās tika ieteiktas un dabā izveidotas prettrokšņu sienas. Pēc objekta nodošanas ekspluatācijā trokšña monitorings netiek veikts, pieņemot, ka prognozes ir bijušas pareizas. Taču Saulkrastu apvedcelsa ietekmes zonā veiktie eksperimentālie mērījumi 4 punktos parāda pretējo - trokšña lìmeņa pārsniegumi dienas laikā $\left(L_{d}\right)$ konstatēti visos mērījuma punktos, arī tur, kur izbūvētas prettrokšña sienas. Eksperimentālo trokšña mērījumu uzdevums bija noteikt arī korelāciju starp trokšņa lìmeni un transporta intensitāti uz apvedceļa. Rezultāti parāda, ka korelācija starp šiem faktoriem ir vāja, tātad trokšņa līmenis tieši nav atkarīgs no transporta intensitātes, bet arī no virknes citu faktoru.
Anda Zandberga, Liga Lieplapa, Dagnija Blumberga, The analysis of noise level on Saulkrasti bypass

The environmental impact assessment (EIA) is an acknowledged method in the world used for estimating the possible changes to the environment caused by proposed development activities, including the development of linear infrastructures. The EIA of planned projects for building or reconstruction of the motorways in Latvia are usually carried out in a short time frame, and therefore the data characterizing current environmental conditions sometimes are not of the best quality. These kind of data gaps cause an inaccurate prognoses on the possible changes to environmental quality after project implementation. Our research demonstrates that this was the case concerning the weak evaluation of sound levels on the Saulkrasti bypass. Within the framework of the EIA, the prognosis of sound levels was elaborated, prooving that, generally, the traffic sound will be within the officially permissible levels, although the problem points are recognized and the erection of sound barriers are proposed. After construction of bypass, however, the noise monitoring has not been carried out in order to verify whether the prognosis are true. In fact, the results of experimental measurements at four points on the Saulkrasti bypass showed the opposite - the noise level in the daytime $\left(L_{d}\right)$ exceeded the acceptable value at all points of the measurements, including the places with installed sound barriers. The task of our experimental measurements on the bypass was also to find a correlation between the noise level and traffic intensity. The results showed that a correlation between these factors is weak, and the noise level is not directly dependant on traffic intensity, but on the total impact of several factors.

Анда Зандберга, Лига Лиеплапа, Дагния Блумберга, Анализ уровня шума на Сулкрастской объездной дороге

Оиенка влияния на окружающую среду (ОВО) является на мировом уровне признаннылм методом прогноза возможных изменений в окружающей среде в зависимости от намеченных работ, в том числе $и$ линейной инфраструктурыл. $\quad$ В Латвии для запланированного строительства дорог и проектов по реконструкиии ОВО обычно происходит в сравнительно короткий период времени, таким образом, полученные данные могут не полностью отображать реальное состояние окружающей среды, что влияет на результаты прогнозов возможных изменений окружающей среды после осуществления намеченных работ. Это относится $u \kappa$ ошибочному прогнозу изменения уровня шума после реализаџии проекта на Саулкрастской объездной дороге. В рамках ОВО, используя метод моделирования, было прогнозировано, что шум от автотранспорта не превысит предельные величины нормативов, но были отмечены проблемные места, где было предложено строительство противошумовых стен. Приняв, что прогнозы были сделаны правильно, после сдачи объекта в эксплуатацию шумовый мониторинг не был проведён. В свою очередь экспериментальные измерения сделанные в четырёх 
точках зонь воздействия Саулкрастской объездной дороги показывают обратное - уровень иума в дневное время превышает норму во всех местах измерений, даже там, где построены противошумовые стены. Задачей экспериментальных измерений было также определить корреляцию между уровнем шума и интенсивностью движения на объездной дороге. Было установлено, что корреляция между этими факторами слабая. Это означает, что уровень шума на прямую не зависит от интенсивности транспортного движения, а от общего влияния ряда отдельных факторов. 